\title{
Tren Keluarga Bersepeda di Era New Normal
}

\author{
Khairunnisa Nurrahmah ${ }^{1}$, Rahmi Safitri², Sumiati ${ }^{3}$, Putri Diesy Fitriani ${ }^{4}$ \\ 1*2,3,4 UIN Sunan Gunung Djati Bandung; ${ }^{1 *}$ khairunnisashasa@gmail.com, 2ipmawati.rahmisafitri@gmail.com \\ ${ }^{3}$ sumiati@uinsgd.ac.id, ${ }^{4}$ putridiesy@uinsgd.ac.id
}

*Penulis Korespondensi

Artikel dikirim: 15 Februari 2021

Artikel Diterima: 14 Juni 2021

Artikel Dipublikasikan: 21 Juni 2021

\begin{abstract}
Abstrak: Dalam mengisi kehidupan di era kebiasaan baru atau New Normal ini masyarakat melakukan kegiatan berolahraga di luar rumah. Salah satu olah raga yang dilakukan adalah bersepeda. Kegiatan ini dilakukan masyarakat dengan tetap menjaga protokol kesehatan. Tulisan ini menyajikan tentang kegiatan anak dan keluarga dalam mengisi era New Normal dengan bersepeda, khususnya kegiatan bersepeda keluarga di kota Bandung. Penelitian ini merupakan penelitian kualitatif lapangan (field research) dengan menggunakan pendekatan deskriptif analitis, dengan teknik pengumpulan data melalui observasi dan wawancara narasumber atau informan. Hasil kajian ini menunjukkan bahwa anggota keluarga melakukan olahraga bersepeda di era New Normal secara bersama-sama pada masyarakat Kota Bandung yaitu dilakukan pada hari tertentu saat kondisi anggota keluarga memungkinkan di pagi hari, lebih sering dilakukan pada hari Ahad, dengan menggunakan sepeda masing-masing atau menggunakan sepeda tandem dengan tujuan selain untuk berolahraga dan kesehatan, menjaga imunitas, tetapi juga untuk kebersamaan keluarga dan menghilangkan kejenuhan setelah berbulan-bulan selalu beraktifitas di dalam rumah. Agar anak-anak juga tidak selalu melakukan kegiatan dengan gadget mereka.
\end{abstract}

Kata Kunci: Bersepeda, Keluarga, New Normal.

\begin{abstract}
In filling life in this era of new habits or New Normal, people do sports outside the home. One of the sports that is done is cycling. This activity is carried out by the community while maintaining health protocols. This paper presents the activities of children and families in filling the New Normal era with cycling, especially cycling activities for families in the city of Bandung. This research is a qualitative field research (field research) using a descriptive analytical approach, with data collection techniques through observation and interviewing informants or informants. The results of this study indicate that children and families do cycling in the New Normal Era in the people of Bandung, which is done on certain days when the conditions of family members allow in the morning, more often on Sundays, by using their respective bicycles or using a tandem bicycle. . The goals and objectives of family cycling are in addition to exercising and health, maintaining immunity, but also for family togetherness and eliminating boredom after months of always activities at home. So that children do not always do activities with their gadgets.
\end{abstract}

Keywords: Cycling, Family, New Normal

\section{Pendahuluan}

Berawal dari adanya virus Corona jenis baru di kota Wuhan, Provinsi Hubei, Cina, yaitu pada penghujung tahun 2019. Telah terjangkit lebih dari separuh jumlah umat manusia di muka bumi - 4,5 miliar orang - di 193 negara dikurung di rumah masing-masing (Afp.com, 18 april 2020). Harian New York Times (1 April 20120) mengungkapkan bahwa para dokter di ruang gawat darurat yang kewalahan menggambarkan kondisi hari-hari ini itu sebagai bersifat "apokaliptik." Gejala penyakit ini 
seperti influenza biasa, yaitu adanya batuk, demam dan hidung berair, sehingga awalnya dianggap remeh, lalu barulah penduduk di muka bumi ini menyadari tentang bahayanya setelah banyaknya jatuh korban (Ali, 2020).

Virus ini sama menularnya dengan influenza, sifatnya ganas dan mematikan (lethal and deadly), meski belum pernah disaksikan umat manusia tandingannya sejak wabah hitam (black plague) di Abad Pertengahan (Eastman, 2009), atau flu Spanyol (Spanish flue) di paruh pertama abad ke-20 (Wibowo, 2009), namun esensinya tetap masih menimbulkan perdebatan.

Merebaknya penyebaran virus ini kemudian dinyatakan sebagai pandemi pada 11 Maret 2020, virus ini cepat menyebar terutama di antara orang-orang selama kontak dekat. Maka, setiap orang diminta untuk menjauhi satu sama lain agar tidak terjadi penyebaran lebih jauh dan menyebabkan korban berjatuhan lebih banyak. Maka, pada 11 Februari, Organisasi Kesehatan Dunia atau World Health Organization (WHO) dalam konferensi pers menetapkan COVID-19 sebagai nama penyakit dan menetapkan langkah-langkah pencegahan untuk mengurangi kemungkinan infeksi termasuk tinggal di rumah, menghindari tempat-tempat ramai, sering mencuci tangan dengan sabun dan air dan setidaknya selama 20 detik, memelihara kebersihan saluran pernafasan, menghindari menyentuh mata, hidung atau mulut dengan tangan yang tidak bersih atau belum dicuci.

WHO menganjurkan kepada masyarakat untuk melakukan strategi menjaga jarak sosial (social distancing) yang bertujuan untuk mengurangi kontak orang yang terinfeksi dengan kelompok besar masyarakat. Upaya ini dilakukan dengan menutup sekolah dan tempat kerja, membatasi perjalanan dan tidak melakukan pertemuan publik besar. WHO dan badan kesehatan lainnya mulai mengganti penggunaan istilah "jarak sosial" dengan "jarak fisik" (physical distancing), untuk mengklarifikasi bahwa tujuan upaya ini adalah untuk mengurangi kontak fisik dengan tetap menjaga hubungan sosial.

Pemerintah Indonesia juga pada akhirnya menetapkan physical distancing berkaitan dengan wabah COVID-19 ini, sebagaimana dinyatakan Presiden Jokowi: "Saatnya kita kerja dari rumah, belajar dari rumah, ibadah di rumah, inilah saatnya bekerja bersama-sama saling tolong menolong dan bersatu padu, gotong royong," (abc, 2020)

Relevan dengan physical distancing tersebut, Pemerintah menerapkan secara bertahap di wilayah Indonesia pembatasan sosial berskala besar (PSBB), merujuk kepada Undang-undang Nomor 6 Tahun 2018 tentang Kekarantinaan Wilayah. Dalam undang-undang tersebut dijabarkan ada empat bentuk karantina: (1) karantina rumah, (2) karantina rumah sakit, (3) karantina wilayah atau biasa dikenal dengan sebutan Lockdown dan (4) pembatasan sosial berskala besar (PSBB). Dalam pandangan Pemerintah, PSBB adalah solusi pencegahan penuluran COVID-19. Ia adalah pembatasan kegiatan tertentu penduduk dalam suatu wilayah yang diduga terinfeksi penyakit dan/atau terkontaminasi sedemikian rupa untuk mencegah kemungkinan penyebaran penyakit tersebut (Sofanudin, 2020). Alasan Pemerintah tidak memilih lockdown sudah dapat diduga pengamat. Pemerintah mengambil langkah pembatasan sosial karena faktor ekonomi. Bila lockdown yang dipilih, maka imbasnya besar, harga yang dibayar terlalu mahal: lenyapnya pendapatan negara di banyak sektor, banyak perusahaan akan merugi dan terpaksa melakukan PHK, ekspor dan impor terganggu, dan jumlah penduduk yang terpapar kemiskinan akan bertambah besar. Faktor keamanan pun menjadi pertimbangan karena akan menerima efeknya yang merugikan (Arum \& Raysara, 2020). 
Meskipun tidak adanya penerapan lockdown, namun kehidupan ekonomi dan aspek psikologis yang dirasakan masyarakat diantaranya berupa kejenuhan, maka pemerintah Indonesia menetapkan kehidupan masyarakat dalam bentuk Kenormalan baru (new normal). adalah sebuah istilah dalam bisnis dan ekonomi yang merujuk kepada kondisi-kondisi keuangan usai krisis keuangan 2007-2008, resesi global 2008-2012, dan pandemi COVID-19. istilah ini dipakai untuk mengimplikasikan bahwa suatu hal yang sebelumnya dianggap tidak normal atau tidak lazim, kini menjadi umum dilakukan.

New normal dilakukan sebagai upaya kesiapan untuk beraktivitas di luar rumah seoptimal mungkin. Kesiapan ini sebagai upaya untuk dapat beradaptasi dalam menjalani perubahan perilaku yang baru. Tentu saja perubahan pola hidup ini diiringi dengan menjalani protokol kesehatan sebagai pencegahan penyebaran dan penularan COVID-19 seperti yang telah diuraikan pada penjelasan di atas, yaitu menjaga jarak dan menjaga kebersihan diri serta menggunakan masker wajah.

Dalam mengisi kehidupan di era kebiasaan baru atau new normal ini ada banyak kegiatan yang dilakukan masyarakat di luar rumah diantaranya berolah raga. Salah satu olah raga yang menarik, murah dan bebas polusi adalah bersepeda. Kegiatan bersepeda ini dilakukan masyarakat dengan tetap menjaga protokol kesehatan. Kegiatan bersepeda ini dilakukan oleh berbagai kalangan dan usia serta jenis kelamin, mulai dari usia anak-anak, remaja hingga orang tua, laki-laki maupun perempuan. Kegiatan bersepeda ini akhirnya menjadi tren menarik di era new normal.

Penelitian ini merupakan penelitian kualitatif lapangan (field research) dengan menggunakan pendekatan deskriptif analitis, yaitu penelitian yang dilakukan untuk mendeskripsikan suatu fenomena sosial dengan teknik pengumpulan data melalui observasi dan wawancara narasumber atau informan. Penelitian deskriptif analitis ini bertujuan untuk menjelaskan dan menganalisa keadaan keluarga yang melakukan aktifitas di Era New Normal pada masyarakat Kota Bandung.

\section{Pembahasan}

\subsection{Konsep Keluarga}

Corona virus disease 2019 (Covid-19) memberikan dampak besar bagi keluarga. Dengan diberlakukannya PSBB selama beberapa bulan merupakan waktu yang tepat untuk meningkatkan kualitas hubungan keluarga. (Suryadi, 2020) Bekerja dari rumah, belajar dari rumah, beribadah dari rumah dan segala sesuatunya dilakukan lebih banyak dirumah. Meskipun terdapat keterbatasan interaksi fisik maupun aktivitas diluar, namun hal tersebut memberikan waktu yang sangat tepat bagi meningkatkan harmonisasi keluarga.

Istilah keluarga menurut undang-undang no 10 tahun 1992 terkait dengan perkembangan kependudukan dan pembangunan keluarga sejahatera, keluarga merupakan unit yang paling kecil dari masyarakat yang terdiri dari suami, isteri beserta anak. Definisi lain menyatakan keluarga itu adalah kumpulan dari dua orang atau lebih dari itu yang melakukan aktivitas kehidupan secara bersama dengan keterikatan aturan juga emosional serta individu yang memiliki peran masing-masing yang merupakan bagian daripada keluarga itu sendiri. (Friedman, 2010)

Fungsi utama dari suatu keluarga adalah dalam aspek afektif, yaitu untuk memperkenalkan serta mempersiapkan anggota keluarganya untuk dapat berhubungan baik dengan orang lain. Selain itu keluarga memiliki fungsi tempat untuk bersosialisasi serta mengembangkan serta melatih anak untuk 
bersosialisasi dengan orang lain, fungsi selanjutnya adalah fungsi reproduksi dengan maksud untuk mempertahankan generasi keluarga, kemudian fungsi ekonomi, yaitu untuk memenuhi kebutuhan keluarga dan terakhir yaitu fungsi keperawatan atau pemeliharaan kesehatan yang artinya untuk mempertahankan kesehatan anggota keluaga agar dapat terus beraktivitas dengan produktif. (Friedman, 2010)

Keluarga merupakan tempat pertama bagi seorang anak untuk belajar dalam hal apapun, peran keluarga tentunya sangat besar dalam perkembangan anak. Hubungan orang tua dan anak yang baik tentunya akan memberikan hal yang positif bagi kedewasaan dan tingkah laku sang anak kelak dimasa depan. Istilah anak jika ditinjau berdasarkan aspek yuridis dapat dikatakan sebagai orang yang belum dewasa (minderjaring) dibawah umur (minderjaringheid) dan juga dapat disebut sebagai anak yang masih dalam pengawasan walinya (minderjarige onvervoodij). (Soeaidy, Sholeh, \& Zulkhair, 2001) hal tersebut diperjelas dengan ketentuan dalam kitab Undang-undang Perdata pasal 330 yang menyatakan bahwa batasan seseorang dikatakan sebagai anak adalah seseorang yang belum berumur 21 tahun atau mereka yang belum menikah.

Al-Ghazali dalam kitabnya Ihya 'Ulum Ad-din mengungkapkan bahwa Anak merupakan amanah bagi orang tuanya. Dilahirkan dengan fitrah yang suci dan menerima segala yang diukirkan atas dirinya. Jika dididik dan dibiasan untuk berbuat baik maka akan tumbuh dengan kebaikan, tetapi jika dididik dan dibiasakan dengan melakukan keburukan maka akan tumbuh dengan terbiasa melakukan sesuatu hal yang buruk. (Usman, 1996). Hal ini mengungkapkan bahwa pola hidup anak sangat bergantung terhadap bagaimana hubungan orang tua dengan anaknya tersebut. Semakin baik hubungan orang tua dengan anak, maka akan semakin baik pula perilaku anak begitupun sebaliknya. Oleh karena itu implikasiya adalah setiap orang tua wajib melindungi serta memberikan kesejahteraan, keterampilan serta membekali pendidikan agama. Karena didalam setiap anak melekat harkat dan martabat serta hak sebagai manusia yang harus dijunjung tinggi.

Peranan orang tua tentunya sangat berpengaruh terkait keberlangsungan hubungan yang berkualitas dalam keluarga. Berkaitan dengan hal tersebut bahwa WHO merilis berbagai panduan bagi orang tua dalam mendampingi anak selama masa pandemi serta proses pengasuhann yang positif dan kondusif. Secara umum dalam masa pandemic covid-19 ini orang tua memiliki peran sebagai pembimbing, pendidik, penjaga, pengembang dan pengawas (Kurniati, Nur Alfaeni, \& Andriani, 2020)

Anak merupakan bagian yang tidak terpisahkan dari sebuah keluarga, sehingga keberlangsungan hidup keluarga tersebut akan tergantung pada pola pendidikan yang diberikan orang tua kepada anakanaknya sebagai penerus dari keluarga tersebut, dan hasil dari pendidikan dari orang tua kepada anakanaknya juga akan dapat berpengaruh besar terhadap kelanjutan keberlangsungan hidup bangsa, Negara dan agamanya. Agar kelak mampu bertanggung jawab dalam keberlangsungan keluarga, bangsa, Negara dan agamanya, maka setiap anak harus diberikan kesempatan yang seluas-luasnya untuk tumbuh dan berkembang secara optimal, baik perkembangan secara fisik, mental, maupun sosial.

Demi tercapainya hal tersebut maka sudah menjadi suatu keniscayaan bagi negara untuk memberikan kepastian hukum sebagai upaya memberikan perlindungan agar dapat mewujudkan kesejahteraan Anak dengan memberikan jaminan terhadap pemenuhan hak-hak anak tanpa perlakuan yang diskriminatif. Maka selanjutnya pemerintah mengeluarkan Undang-Undang No. 35 tahun 2014 
tentang Perubahan Atas Undang-Undang No. 23 tahun 2002 tentang Perlindungan Anak yang selanjutnya di sebut dengan Undang-Undang Perlindungan anak (UUPA).

Berdasarkan Pasal 1 UUPA, yang dimaksud dengan Anak adalah seseorang yang belum berusia 18 (delapan belas) tahun, termasuk anak yang masih dalam kandungan. Dengan adanya spesifikasi usia dalam peraturan tersebut, maka menjadi jelas bahwa anak yang dijamin perlindungannya dalam undang-undang ini adalah dimulai sejak dalam kandungan sampai usia 18 tahun. Selanjutnya negara mengatur berbagai hak yang di lindungi bagi setiap anak, diantaranya sebagaimana di atur dalam Pasal 6 UUPA menyatakan bahwa setiap anak berhak untuk beribadah menurut agamanya, berpikir, dan berekspresi sesuai dengan tingkat kecerdasan dan usianya dalam bimbingan Orang Tua atau Wali. Dalam hal ini beribadah menurut agamanya masing-masing merupakan hak yang diberikan oleh negara kepada anak dengan bimbingan orang tua atau wali anak tersebut yang disesuaikan dengan tingkat kecerdasan dan usia nya, dengan demikian faktor bimbingan orang tua sangat penting bagi anak agar dapat menjalankan hak nya dalam melakukan ibadah sejak dini.

Selanjutnya didalam Pasal 14 UUPA menyatakan bahwa setiap anak berhak memperoleh pendidikan dan pengajaran dalam rangka pengembangan pribadinya dan tingkat kecerdasannya sesuai dengan minat dan bakat. Dalam hal ini pemerintah memberikan jaminan hak pendidikan kepada anak sesuai dengan minat dan bakat masing-masing, artinya tidak boleh adanya paksaan dari orang tua kepada anak dalam mendapatkan pendidikan yang tidak sesuai dengan bakat dan kemampuannya. Terkadang terjadi tindakan yang secara tidak disengaja yang dilakukan orang tua kepada anak-anak nya dengan cara memberikan pendidikan kepada anak yang tidak sesuai dengan bakat masing-masing akan tetapi mengikuti keinginan orang tua, sehingga hasilnya anak tidak menjadi seperti harapan orang tua, sehingga kecerdasan orang tua dalam membaca minat dan bakat anak sejak dini merupakan hal yang penting agar tidak salah mengarahkannya.

Hak lain yang diberikan oleh negara sebagaimana diatur dalam Pasal 9 ayat 1 menyatakan bahwa setiap anak berhak untuk diasuh oleh Orang Tuanya sendiri, kecuali jika ada alasan dan/atau aturan hukum yang sah menunjukkan bahwa pemisahan itu adalah demi kepentingan terbaik bagi anak dan merupakan pertimbangan terakhir. Dalam hal ini hak asuh anak seharusnya diberikan oleh orang tuanya secara langsung terkecuali ada alasan-alasan lain yang dibenarkan secara hukum. Banyak cara bagi orang tua dalam mengasuh anak, tergantung pola asuh yang dibangunnya, dalam hal ini pola asuh anak merupakan suatu proses yang ditujukan untuk meningkatkan serta mendukung perkembangan fisik, emosional, sosial, finansial, dan intelektual seorang anak sejak bayi hingga dewasa. Sehingga keberadaan Orangtua merupakan guru pertama dan utama untuk anak dalam mempelajari banyak hal, baik secara akademik maupun kehidupan secara umum.

Pengasuhan anak yang dilakukan oleh orang tua tidak akan sempurna tanpa adanya campur tangan dan dukungan dari Pemerintah dalam memberikan sarana dan prasarana, maka selanjutnya dalam Pasal 22 diatur bahwa Negara, Pemerintah, dan Pemerintah Daerah berkewajiban dan bertanggung jawab memberikan dukungan sarana, prasarana, dan ketersediaan sumber daya manusia dalam penyelenggaraan perlindungan anak. Dukungan sarana dan prasarana tersebut diberikan baik dalam bentuk sarana pendidikan, sarana bermain ataupun yang lainnya. Salah satu bentuk cara bermain anak yaitu dengan belajar bersepeda sejak kecil, bermain seperti ini dianggap efektif karena selain 
menyenangkan juga menjadi sehat dan dapat dilakukan sejak kecil sampai dewasa, terlebih saat ini kondisi negara sedang dalam dilanda pandemi covid-19, maka bermain sepeda merupakan suatu model tren baru masyarakat yang dilakukan mulai dari anak-anak sampai orang dewasa, maka salah satu tugas pemerintah adalah dengan cara memberikan sarana dan prasarana yang aman dan nyaman bagi masyarakat.

Berhubungan dengan kewajiban dan bertanggung jawab orang tua terhadap anak di atur dalam Pasal 26 ayat 1 yang menyatakan bahwa orang tua berkawajiban dan berkewajiban untuk:

- $\quad$ Mengasuh, memelihara, mendidik, dan melindungi Anak;

- Menumbuhkembangkan Anak sesuai dengan kemampuan, bakat, dan minatnya;

- Mencegah terjadinya perkawinan pada usia Anak; dan

- Memberikan pendidikan karakter dan penanaman nilai budi pekerti pada Anak.

Keluarga merupakan institusi terkecil dalam sebuah lingkungan masyarakat yang memiliki peran yang signifikan dalam pembentukan karakter anggotanya terutama anak. Dalam hal ini Keluarga memiliki struktur sosial dan sistem tersendiri. dan yang merupakan sekumpulan orang yang tinggal dalam satu rumah yang masih mempunyai hubungan kekerabatan/hubungan darah karena perkawinan, kelahiran, adopsi dan lain sebagainya

Nampaknya, masalah keluarga pada saat ini maupun di masa mendatang akan semakin kompleks karena banyak perubahan dalam masyarakat yang berlangsung sangat cepat. Selain itu, tantangan yang dihadapi keluarga juga semakin beragam. Dalam realitanya, telah terjadi perubahan sosial yang pesat sehingga menimbulkan adanya keresahan karena nilai-nilai lama yang diandalkan oleh komunitas kurang dapat dimanfaatkan lagi. Kondisi tersebut sangat berpengaruh terhadap perubahan peran yang dimainkan oleh suami istri, yang berdampak pada relasi antara suami istri dalam keluarga. (Muslih, 2007)

Ajaran Islam memiliki konsep unik dalam proses pendidikan anak usia 1 hingga 21 tahun. Ali bin Abi Thalib Ra menyampaikan bahwa ada tiga kelompok dalam mode pengasuhan anak, yakni : (Husnaini, 2013)

1. Kelompok 7 tahun pertama (usia 0-7 tahun), perlakukan anak sebagai raja.

Memperlakukan saat anak masih usia dibawah 7 tahun dengan hati yang ikhlas dan bahagia serta ketulusan yang luar biasa merupakan sesuatu yang sangat mempengaruhi pola perkembangan perilaku sang anak. Seperti ketika proses menidurkan sang anak dengan mengelus punggungnya sampai dengan tertidur, maka effect kedepan akan memeberikan perlakuan yang baik pula seperti memijat orang tuahya saat sedang kelelahan, jika kita langsung menghampiri anak ketika anak membutuhkan orang tuanya, maka kelak ia akan langsung menghampiri orangtuanya pula saat dibutuhkan. Dan saat orang tua selalu memperlakukan sang anak dengan riang dan penuh dengan kegembiraan maka kelak sang anak akan menjadi individu yang membahagiakan serta menyenangkan bagi orang lain serta bertanggung jawab. Oleh Karena itu, jika para orang tua memperlakukan anaknya seperti seorang rajanya pada saat rentang usia ini, maka kelak anaknyapun akan menyayangi serta memperlakukan orang tuanya sebagai raja maupun ratunya.

2. Kelompok 7 tahun kedua (usia 8-14 tahun), perlakukan anak sebagai tawanan. 
Memasuki rentan usia ini adalah saatnya orang tua memberikan ketegasan pada anaknya serta memberikan tanggung jawab. Saat yang tepat pula bagi orang tua memberikan pengetahuan bagi anaknya terkait dengan agama, baik sesuatu yang diperintahkan maupun sesuatu yang tidak diperbolehkan. Seperti diperintahkan untuk menjalankan Sholat. Sama halnya saat Rasulullah mulai memerintahkan seorang anak untuk melakukan sholat wajib pada usia 7 tahun. Memberikan sistem reward bagi anak yang telah melaksanakan kewajibannya dan melakukan sistem punishment dengan sesuatu yang wajar ketika melanggar merupakan waktu yang tepat juga diberlakukan pada saat rentang usia ini agar anak dapat lebih memahami arti penting dari sebuah komitemen. Namun hal tersebut juga harus diperhatikan bahwa perlakuakan anak tidak harus sama setiap orangnya karena setiap anak memiliki kekhasannya masing-masing.

3. Kelompok 7 tahun ketiga (usia 15-21 tahun), perlakukan anak sebagai sahabat.

Memperlakukan anak seperti seorang sahabat adalah saat yang tepat dilakukan pada saat rentang usia ini. Berbicara dari hati kehati dalam setiap momen, memberikan teladan yang baik juga mendengarkan keluhan atausaran dan masukan dari sang anak. Libatkan sang anak dalam pengambilan keputusan yang ringan-ringan. Sehingga nantinya sang anak merasa sangat dibutuhkan oleh orang disekitarnya dan akan memberikan rasa peduli yang lebih kepada orang lain dan dapat menjadi seseorang yang solutif dimasa depan. Dan pada saat ini anak sudah mulai memasuki masa aqil baligh dan sudah mulai beranjak remaja ke dewasa. Anak akan mengalami perubahan fisik juga mental yang mencakup spiritual, soial dan lingkungan, sehingga sangat mungin akan mengalami masalah-masalah yang dihadapinya. Dengarkan curahan hati dan fikirannya jangan sampai sebagai orang tua hanya bisa menghakimi tapi memberikan solusi atas masalah yang dihadapinya. Lalu berikan anak kebebasan dalam bertindak maupun berteman namun mesti tetap dengan pengawasan baik orang tuanya sehingga nanti anak memiliki pribadi mandiri dan berperilaku baik.

M. Jamalaudin Mahfuzh dalam Sutrisno memberikan gambaran terkait metode pola pendidikan Islam dalam keluarga meliputi : (Sutrisno, 2017)

1. Menenamkan iman sedari kecil, seperti bahwa halnya mengadzankan anak yang baru lahir, hikmah dari hal itu adalah upaya agar kalimat pertama yang didengar oleh seorang anak yang baru dilahirkan adalah kalimat yang menyatakan tentang kebesaran Allah Swt dan memperkuat iman nya agar selalu taat menjalankan perintah agama;

2. Latihan beribadah sejak dini, implikasi dari menanamkan iman yang kuat maupun akidah yang kuat bagi sang anak, orang tua wajib memberikan arahan juga mengajarkan terkait proses ibadah yang wajib maupun sunnah kepada sang anak sejak kecil, sehingga kelak saat anak sudah beranjak remaja hingga dewasa melakukan ibadah sudah menjadi kebisaan yang baik dan tidak meningalkannya walaupun dalam keadaan darurat sekalipun;

3. Memberikan pemahamanan kepada sang anak terkait dengan sesuatu yang halal dan haram;

4. Membiasakan anak belajar. Karena belajar itu merupakan suatu kewajiban dan dengan belajar anak akan mudah membedakan mana yang benar dan yang salah, yang halal maupun yang haram. Dengan membiasakan belajar sejak dini, bukan hanya belajar pelajaran sekolah namun belajar 
terkait dengan agama, membaca dan mengahafal al-quran dan mengenal ajaran-ajaran agama. Maka saat menginjak usia dewasa ajaran-ajaran tersebut akan menyatu dengan kepribadiannya;

5. Memberi reward dan punishment yang wajar pada sang anak. Dalam Islam memberikan reward mapun punishment bagi anak yang sudah baligh diperbolehkan. Namun memafkan dan memberi nasihat terlebih dahulu sangat dianjurkan karena sang anak masih dalam keadaan yang labil dan memiliki pemikiran yang belum matang;

6. Menjadikan seorang anak sebagai sahabat bagi kedua orang tuanya. Persahabatan orang tua dan anaknya akan memberikan hubungan yang harmonis dalam keluarga. merasa saling membutuhkan satu sama lain dan saling memberikan masukan diantara mereka membuat kualitas hubungan keluarga menjadi lebih baik dan terasa hidup.

7. Memberikan pemahaman untuk berlaku sopan kepada orang tua atau kepada orang yang lebih tua, seperti meminta izin untuk melaksanakan sesuatu.

8. Berlaku adil pada setiap anak. Adil bukan berarti memeberikan sesuatu yang sama bagi setiap anaknya namun proporsional. Hal tersebut akan menghindari perselisihan atau permusahan antar anak akibat ketidakadilan tersebut.

\subsection{Olahraga Bersepeda}

Menurut International Council of Sport and Education Olahraga merupakan kegiatan yang berbau fisik dan berkonfrontasi dengan alam yang mengadung sifat permainan dengan disertai perjuangan individu maupun kelompok.(Lutan, 2013). Selain itu terdapat UU No.3 tahun 2005 tentang Sistem Keolahragaan Nasional menyatakan bahwa olahraga adalah "segala kegiatan yang sistematis untuk mendorong, membina, serta mengembangkan potensi jasmani, rohani, dan social.” Berdasarkan definisi diatas dapat dirumuskan bahwa definisi olahraga adalah aktifitas individu maupun kelompok yang dilakukan secara sitematis yang bersifat permainan dengan tuhjuan untuk mengembangkan potensi jasmani, rohani serta sosial

Olahraga merupakan hal yang sangat bermanfaat bagi tubuh manusia. Jika diilustrasikan tubuh manusia yang tidak melakukan aktivitas olahraga seperti mesin yang tidak pernah digunakan, semakin lama mesin itu tidak digunakan maka akan semakin cepat rusak karena tidak terlatih untuk menjalakan sebagaimana fungsinya. Begitupun manusia yang tidak melakukan aktivitas olahraga maka akan mendapatkan permaslahan yang membahayakan tubuh tersebut. Otot-otort menjadi terlatih dengan berbagai fungsinya, aliran darah menjadi normal serta sirkulasi oksigen dalam tubuh menjadi lancar sehingga daya tahan imun menjadi baik. (Fatkurahman, 2010).

Melakukan aktivitas berolahraga menjadi salah satu cara untuk mendapatkan kebugaran jasmani. Kebugaran jasmani atau juga bisa dikenal dengan istilah Physical Fitness merupakan kesesuaian fisik dengan jenis aktivitas yang dilakukan sehari-hari secara efisien yang tidak menimbulkan kelelahan yang berberlebihan sehingga tubuh masih dapat menikmati sisa waktu luangnya. Untuk mendapatkan kebugaran jasmani yang optimal harus dilakukan dengan perencanaan yang sistematik serta pemahaman tentang bagaimana menjalani pola hidup yang sehat bagi setiap individu dengan beberapa upaya seperti: makan makanan sehat, istirahat yang cukup dan berolahraga. (Djoko Pekik, 2004) 
Bersamaan dengan masa pandemi Covid-19 yang terjadi di Indonesia. Masyarakat berbondongbondong melakukan aktivitas hidup sehat salah satunya melakukan aktivitas olahraga lebih intens. Melakukan aktivitas berolahraga dengan sendiri-sendiri maupun kelompok, indoor maupun outdoor, terdapat berbagai macam pilihan jenis olahraga yang dapat dilakukan oleh masyarakat termasuk bersepeda.

Bersepeda merukan aktvitas olahraga yang digemari oleh semua kalangan masyarakat. Selain dapat melakukan aktivitas olahraga bersepeda juga dapat dikatakan sebagai ajang rekreasi bagi setiap yang melakukannya. Berbicara mengenai sejarah keberadaan sepeda merupakan sejarah yang panjang, bermula dari bentuknya yang sangat sederhana, memiliki roda tiga sampai dengan sepeda modern dengan berbagai jenis inovasi dan kreatifitas pembuatnya yang disesuaikan dengan kebutuhan sepeda itu sendiri. Sepeda ditemukan oleh Baron Karls Drais Von Sauerborn di Jerman pada tahun 1817. Sepada yang dibuat oleh Karls Drais merupakan sepeda beroda tiga tanpa pedal yang digunakan untuk menunjang pekerjaannya sebagai pengawas hutan dan hal tersebut menjadi awal mula berkembanganya teknologi sepeda seperti sekarang ini. (Aunur Rofiq, 2020).

Sepeda berasal dari Bahasa Prancis: vélocipède /ve.lo.si.ped/, melalui bahasa Belanda: vélocipède /velosi'pe:da atau kereta angin merupakan kendaraan roda dua mapun tiga yang sejajar, dibantu dengan pedal yang terhubung dengan roda yang terdapat dibelakang serta memiliki setang sebagai laju kendali dan kursi sepeda sebagai tempat duduk (Gear, 2020) sepeda memiliki banyak manfaat, dari sisi medis bersepeda dapat mengontrol berat badan, menjaga kesehatan jantung, mengurangi risiko diabetes, meningkatkan kesehatan mental serta meminimalisir risiko penyakit lainnya.

Di Indonesia sendiri, sepeda diperkenalkan pada masa kolonial Belanda. Orang Belanda membawa sepeda sebagai alat transportasi yang dapat dikatakan mewah, hanya masyarakat kelas atas yang dapat memiliki sepeda. Seiring dengan perkembangan teknologi transportasi, kedudukan sepeda mulai tergeser dengan kendaraan bermotor, sedangakan sepeda buatan tahu 1930-an segera manjadi barang lama yang mudah untuk ditinggalkan.

Berdasarkan dengan apa yang telah dipaparkan di atas, olahraga sepeda merupakan salah cara untuk melatih kebugaran jasmani, berikut beberapa program latihan kebugaran jasmani dengan olahraga sepeda: Pertama, harus dimulai dengan pemanasan dan di akhiri dengan pendinginan. Pemanasan atau yang biasa disebut dengan istilah warming up mesti dilakukan terlebih dahulu sebelum melaksanakan olahraga. Melakukan pemanasan yang benar akan sangat meminimalisir tejadinya cidera dikarenakan merasa shock karena tubuh dipaksa untuk beralih ke aktivitas dengan intensitas tinggi dengan mendadak dan membuat bersepeda menjadi lebih nyaman. Cara melakukan pemanasan dengan efektif dengan melakukan bersepeda itu sendiri, dimulai dengan mengayuh sepeda secara perlahan, dan secara perlahan pula ditingkatkan sampai dengan target intensitas jantung yang cukup tinggi. Pada saat akan mengakhiri, dilakukan pendinginan atau biasa disebut dengan cooling down dengan melakukan mengayuh sepeda dengan intensitas rendah setelah melakukannya dengan intensitas tinggi yang berlangsung sekitar lima menit. Kedua, memiliki takaran bersepeda dalam melatih kebugaran, terdapat tiga ukuran untuk dapat melatih kebugaran jasmani yaitu, diperlukan latihan minimal 3 kali per minggu, dilakukan dengan intensitas 60 - 90\% detak jantung yang dapat diketahui dengan rumus 220 - umur. Dan selanjutnya durasi dalam melakukan olahraga bersepda, dengan melakukan latihan sekitar 15 
menit sampai dengan 1 jam akan tampak perubahan kondisi tubuh kira-kira setelah berlatih selama 8 sampai dengan 12 minggu. Bukan lamanya waktu dalam sekali latihan yang dijadikan patokan tetapi penambahan waktu per setiap sesi latihanya. Ketiga program olahraga bersepeda harus dilakukan dengan cara yang tepat, seperti melakukannya secara rutin dengan hari berselang, tidak dianjurkan melakukan olahraga bersepeda dengan tenggang waktu istirahat yang lama. (Fatkurahman, 2010)

Olahraga sepeda selain untuk menjaga kebugaran jasmani beserta rohani, namun dapat dikategorikan pula sebagai olahraga wisata (Sudiana, 2018). Mengapa demikian, salah satu jenis sepeda memberikan nuansa atau ciri khas dari daerahnya masing-masing, seperti sepeda onthel yang menunjukan kedaerahan di Indonesia seperti di daerah Yogyakarta, sepeda gunung yang berfungsi untuk melakukan olahraga sepeda menuju destinasi wisata alam seperti gunung dan maish banyak lagi. Oleh karena itu berolahraga sepeda memang banyak digemari baik dari sisi kalangan usia di era new normal ini.

Olahraga bersepeda yang dilakukan secara rutin menjadi sesuatu yang solutif untuk mengurangi dampak risiko penyakit serta menjadikan gaya hidup yang lebih aktif dan sehat. Berikut beberapa kelebihan olahraga bersepeda dibandingkan dnegan yang lainnya :

- Memiliki efek samping yang rendah, sehingga dalam melaksanakan olahraga bersepeda tidak akan mengalami ketegangan atau cedera yang berlebihan dibanding olahraga fisi yang lain;

- Melatih otot untuk lebih kuat lagi, dibuktikan pada saat kaki mengayuh pedal sepeda;

- Dapat dilakukan dengan mudah, tidak memerlukan keahlian khusus dalam berolahraga sepeda, semua kalangan tua muda bias melakukan olahraga sepeda;

- Memperkuat stamina dan daya tahan tubuh;

- Hemat waktu, selain sepeda dilakukan untuk berolahraga namun bersepeda juga dapat digunakan sebagai alat tranportasi sama halnya dengan alat transportasi lainnya.

Adapun manfaat lainnya dalam melakukan aktivitas bersepeda menurut Frobose ialah : (Muslih, 2007)

- Olahraga sepeda adalah olahraga yang dapat dilakukan oleh berbagai elemen masyarakat dengan kriteria tubuh apapun, baik yang memiliki ukuran tubuh yang besar maupun kecil dan obesitas sekalipun tanpa takut adanya cidera. Karena dalam bersepeda memliki tingkat tekanan lutut yang rendah dan cara yang tepat untuk memperkuat tulang rawan.

- Bersepeda merupakan salah satu cara memperbaiki performa pemompaan jantung, jatung akan bekerja lebih efisien sehingga dapat mengurang tekanan pada darah secara langsung serta memperlancar sirkulasi darah dan menghindari risiko penyakit jatung

- Berolahraga dengan berepa juga dapat meningkatkan imun tubuh sehingga tubuh memiliki daya tahan yang baik untuk melindungi tubuh dari bahaya bakteri serta bahaya virus.

Kegiatan bersepeda merupakan olahraga yang mudah dilakukan oleh khalayak umum, tidak mengenal muda ataupun tua karena sangat simpel. Penelitian manfaat bersepeda juga telah dilakukan di Denmark yang hasilnya olahraga bersepeda dapat mengurangu $40 \%$ resiko kematian perempuan ataupun laki-laki (Archives of Internal Medicine, 2000). Selain itu, di American Journal of Public Health tahun 1986 terdapat laporan bahwa dengan bersepeda kita dapat memiliki umur yang panjang 
dibandingkan dengan orang-orang yang tidak melakukan olahraga bersepeda. Terdapat juga kutipan dari Journal of Cardiovascular Pharmacology, 1995 bahwa dengan bersepeda, kita akan banyak membakar lemak didalam tubuh, karena dengan melakukan olahraga bersepeda bisa meningkatkan metabolisme tubuh dan dapat membantu menurunkan berat badan kita. Serta mengatur dan mengontrol tekanan darah didalam tubuh kita agar tetap normal.

Kondisi olahraga bersepeda di Indonesia sebagaimana yang tertuang dalam Undang-Undang Nomor 22 Tahun 2009 tentang lalu lintas Angkutan jalan, sepeda termasuk dalam kategori kendaraan tidak bermotoryang digerakkan oleh manusia. Untuk itu peraturan tentang cara penggunaannya dapat dilakukan dengan peraturan Daerah. Menurut Syambudi \& Setiawan (2020), Toto Sugirto selaku cofounder serta pembina Bike2Work menegaskan bahwa pemerintah harus memenuhi hak para pesepeda. Undang-Undang Nomor 222009 tersebut yang mengatur hak dan rasa aman bagi sepeda harus dipenuhi oleh pemerintah dengan mengontrol lalu lintas agar hak dan kewajiban para pesepeda terpenuhi. Dengan demikian keamanan para pesepeda dapat terjamin karena terpenuhinya hak dan kewajiban mereka.

Meskipun tanggapan mengenai fenomena bersepeda ditengah pandemi menimbulkan banyaknya kontroversi, namun sebenarnya juga memberikan manfaat bagi para pesepeda. Manfaat yang sanagt dirasaakan oleh para pesepda yakni memberikan kekuatan serta kekebalan tubuh yang lebih baik. Terutama dimasa pandemi seperti saati ini, sehat menajadi sesuatu yang sangat berharga serta sangat mahal. Saat ini semua elemen masyarakat sedang bersikukuh untuk menerapkan pola hidup sehat serta berlomba-lomba untuk tetap sehat dan kuat pada masa pandemi ini saat ini. Selain meminum vitamin atau imun booster berolahraga tentunya menjadi hal yang harus dilakukan oleh tubuh manusia. Namun behubung pada masa-masa seperti ini tempat olahraga menjadi sangat sulit dicari karena sebagian besar dari tempat-tempat itu tutup, maka bersepeda adalah cara tebaik untuk tetap melakukan olahraga rutin untuk menjada kebugaran tubuh. Hal itu diperkuat oleh pernyataan seorang dokter di Jerman, Michael Barczok yang menerangkan bahwa dengan berolahraga sepeda dapat mempelancar saluran darah dalam tubuh manusia dan memberikan kesempatan yang bagus pula untuk melakukan pertukaran oksigen dan karbondioksida pada tubuh, sehingga dengan manfaat tersebut membuat paruparu bekerja dengan baik dan terhindar dari virus membahayakan,

\subsection{Kegiatan Bersepeda Keluarga Pada Era New Normal Di Kota Bandung}

Kegiatan bersepeda di era new normal atau masa Pembatasanm Sosial Berskala Besar (PSBB) dilakukan oleh masyarakat dari semua kalangan dan jenis kelamin, perempuan, laki-laki, anak-anak dan orang dewasa. Kegiatan bersepeda dilakukan pada hari-hari tertentu, biasanya kegiatan bersepeda lebih ramai dilakukan pada hari Sabtu atau Ahad pagi. Demikian halnya kegiatan bersepeda dilakukan oleh anak dan keluarganya pada hari-hari tertentu pada saat kondisi seluruh anggota keluarga memungkinkan, biasanya pada hari Ahad pagi. Kegiatan ini tetap dilakukan keluarga dan anggota masyarakat luas dengan tetap menjaga protokol kesehatan.

Kegiatan bersepeda keluarga dilakukan dengan menggunakan sepeda sendiri-sendiri, bahkan tak jarang menggunakan sepeda tandem, yang dapat digunakan bersama-sama sekaligus, antara ayah, ibu dan anak-anak mereka. 
Aktivitsa bersepeda keluarga, berdasarkan hasil wawancara penulis pada keluarga yang melakukan olahraga bersama di stadion Gelora Bandung Lautan Api (GBLA) kota Bandung dan di lingkungan komplek Cempaka Arum terdekat di kota Bandung, diperoleh jawaban bahwa selain bersepda dengan tujuan untuk berolahraga dan kesehatan, menjaga imunitas, tetapi juga untuk kebersamaan keluarga dan menghilangkan kejenuhan setelah berbulan-bulan selalu beraktivitas di dalam rumah juga untuk meminimalisir penggunaan gadget bagi anak-anak. Berdasarkan jawaban itu, dapat difahami bahwa manfaat bersepeda keluarga ternyata memberi dampak kesehatan fisik dan psikis.

\section{Kesimpulan}

Hasil kajian ini menunjukkan bahwa anak dan keluarga melakukan olahraga bersepeda di Era New Normal pada masyarakat Kota Bandung yaitu dilakukan pada hari tertentu saat kondisi anggota keluarga memnungkin di pagi hari, lebih sering dilakukan pada hari Ahad, dengan menggunakan sepeda sendiri-sendiri atau menggunakan sepeda tandem. Maksud dan tujuan bersepeda keluarga yaitu selain untuk berolahraga dan kesehatan, menjaga imunitas, tetapi juga untuk kebersamaan keluarga dan menghilangkan kejenuhan setelah berbulan-bulan selalu beraktifitas di dalam rumah. Agar anak-anak juga tidak melulu melakukan kegiatan kegiatan dengan gadget mereka. Manfaat bersepeda keluarga ternyata memberi dampak kesehatan fisik dan psikis.

\section{Referensi}

abc. (2020). Imbauan Social Distancing Diberlakukan, Apa yang harus kita kerjakan? Tempo.Co. Retrieved from https://www.tempo.co/abc/5395/imbauan-social-distancing-diberlakukan-apayang-harus-kita-kerjakan

Ali, S. (2020). General Report of Corona Virus. Retrieved from MSc Botany website: https://www.researchgate.net/publication/340434344_General_Report_of_Corona_Virus/link/5 e887e784585150839bdce56/download

Arum, R., \& Raysara, A. (2020). Pembatasan Sosial Di Indonesia Akibat Virus Corona Ditinjau Dari Sudut Pandang Politik. LawArXiv. https://doi.org/10.31228/osf.io/g8ny3

Aunur Rofiq. (2020). No Title. Retrieved from Malang Times.Com website: https://www.malangtimes.com/baca/32264/20181017/134600/sejarah-penemuan-sepedadan-perkembangannya-di-indonesia

Djoko Pekik. (2004). No Title. Bugar Dan Sehat Dengan Olahraga.

Eastman, J. T. (2009). The Making of a Pandemic: Bubonic Plague in the 14th Century. Journal of Lancaster General Hospital, 4(1), 10-17. Retrieved from http://www.jlgh.org/JLGH/media/Journal-LGH-Media-Library/Past Issues/Volume 4 - Issue 1/v4_i1_Eastman.pdf

Fatkurahman. (2010). Menjaga Kebugaran Jasmani Dengan Bersepeda. Pendidikan Kesehatan Dan Rekreasi FIK-UNY Abstrak, 1-25.

Friedman, M. (2010). Buku Ajar Keperawatan Keluarga (Edisi ke-5). Jakarta: EGC.

Gear, F. (2020). Sepeda.

Husnaini, M. (2013). Parenting Barat dan Parenting Islam. Dakwatuna.Com. Retrieved from 
https://www.dakwatuna.com/2013/02/22/28212/parenting-barat-dan-parentingislam/\#axzz6mV9Wd8Sf

Kurniati, E., Nur Alfaeni, D. K., \& Andriani, F. (2020). Analisis Peran Orang Tua dalam Mendampingi Anak di Masa Pandemi Covid-19. Jurnal Obsesi : Jurnal Pendidikan Anak Usia Dini, 5(1), 241. https://doi.org/10.31004/obsesi.v5i1.541

Lutan, R. (2013). Manusia dan Olahraga. Journal of Chemical Information and Modeling, 53(9), 16891699.

Muslih, M. (2007). Bangunan Wacana Gender. Ponorogo: Centre for Islamic and Occidental Studies (CIOS).

Soeaidy, Sholeh, \& Zulkhair. (2001). Dasar Hukum Perlindungan Anak. Jakarta: Novindo Pustaka Mandiri. Sofanudin, A. (2020, April 14). Cara Agama Hadapi Corona. Wartanasional.Com.

Sudiana, I. K. (2018). Dampak Olahraga Wisata Bagi Masyarakat. Jurnal IKA, 16(1), 55-66.

Sutrisno, A. (2017). Metode Pendidikan Anak dalam Keluarga Menurut Abdullah Nashih Ulwan dan Relevansinya dengan pendidikan Anak dalam Keluarga di Kelurahan Majapahit Kota Lubuklinggau. 2(2), 203-215.

Usman, J. S. (1996). Filsafat Pendidikan Islam. Jakarta: PT. Raja Grafindo Persada.

Wibowo, P. et. a. (2009). Yang Terlupakan: Sejarah Pandemi Influenza 1918 di Hindia Belanda. Depok: Kerjasama Unicef Jakarta dan FBIP Universitas Indonesia. 